\title{
Public debt and private consumption in Asia Pacific countries: Is there evidence for Ricardian equivalence?
}

\author{
Suhal Kusairi \\ School of Social and Economic Development, \\ Universiti Malaysia Terengganu \\ subal@umt.edu.my \\ Vinus Maulina \\ Faculty of Economics and Business \\ Universitas Kanjuruban Malang \\ vinusmaulina@unikama.ac.id \\ Farah Margaretha \\ Faculty of Economics and Business \\ Universitas Trisakti \\ farahmargaretha@trisakti.ac.id
}

Abstract. The study analyses the effect of public debt on private consumption. It indirectly tests whether a Ricardian equivalence proposition exists in differentiated financial development for the yearly data of 18 Asia Pacific countries from 1990 to 2017 using dynamic heterogeneous panel data analysis. The results allow concluding that public debt and private consumption have a long-term co-integrated relationship, and in the general approach, Ricardian equivalence does exist in both long and short term. This implies that an increase in public debt does not increase private consumption because consumers expect governments to raise taxes to service debt such as principal and interest payments. But under the traditional approach Ricardian equivalence does not exist, thus, public debt does affect private consumption. In addition, income, capital accumulation, government expenditure, real interest rate and inflation have a positive effect on private consumption. The key implication of these results is that financial development does not provide evidence for the existence of Ricardian equivalence as it does not have a different effect for different countries.

Received:

November, 2018

1st Revision:

January, 2019

Accepted:

February, 2019

DOI:

$10.14254 / 2071$ $8330.2019 / 12-1 / 3$

Keywords: Public Debt, Private Consumption, Ricardian Equivalence.

JEL Classification: E62, E21, H31. 


\section{INTRODUCTION}

Economic activity is determined by demand and supply, such as domestic and foreign demand of commodities and the supply thereof. One of the important demands is private consumption as a component of aggregate expenditure, which depends on income and taxes. When income increases, then private consumption increases too. On the other hand, when taxes increase, then private consumption decreases. In addition, income tax is the main government revenue to finance government spending; if government revenue is not able to cover all expenditures, the government should take the initiative to borrow or raise taxes. An interesting point here, therefore, is whether government should reduce tax rates or increase debt, and what would the effect on economic activities be?

Economists have provided various answers to the above question. The Keynesian view states that government may reduce taxes, indirectly raising the deficit but increasing private consumption because disposable income increases. The opposite Ricardian view states that changes in the government budget along a certain path brings no effect on private consumption because individuals as taxpayers will take into account the government's decision into their infinite horizon of consumption patterns. The correct answer will help policy makers to manage the economy of a country because private consumption is one of the most important components in driving national economies.

Empirical data provides evidence that almost all Asia Pacific countries have a certain amount of public debt, both developed to undeveloped ones. The annual report (2010) provides information on Malaysia, where the average annual increase was $7.4 \%$ for the period from 2000 until 2009. This growth surpassed the average growth of GDP by $4.8 \%$ and accounted for more than two-thirds of the overall GDP growth. According to the data from (Stats Curious, 2013), Japan is the country with the highest debt levels, up to $226 \%$ of gross domestic product, followed by Singapore with 106\%, Malaysia with 53\% of GDP, South Korea at $60 \%$, Indonesia with its $27 \%$ of GDP, Pakistan with $30 \%$ Laos has $15 \%$ and Bhutan is at $8 \%$ of GDP.

Changes in private consumption expenditure are due to positive or negative economic factors, such as public debt, government spending (Kochin; 1974;Kormendi, 1983) and inflation (Oseni, 2016). This means that when a country's economy slows down, consumers will start to take greater care over their own expenses. This will lead to a fall in economic activity. Therefore, the government in order to boost the economy will carry out various initiatives such as capital injections and debt financial assistance to cover the budget deficit. Similar to inflation is the interest rate: if the latter increases, then purchasing power and consumption are expected to fall (Li, Wei \& Xu, 2017; Siew-Voon, Baharumshah \& Mohamad Shariff, 2017). When public debt increases, private consumption is expected increase or remain stable. The Ricardian Equivalence states that an increase in public debt is met with an indifferent response by users because rising debt is expected to be followed up by future taxes (Kormendi, 1983).

This study focuses on and contributes to the literature on public debt and private consumption in Asia Pacific countries with various financial development levels, from undeveloped to developed countries. More specifically, we concentrate on explanation of the relationship between public debt and private consumption. Asia Pacific (in other words, Asia and Oceania countries) is a region with the area of 29.32 million square kilometers, with some areas still being under contention. According to the United Nations (UN) there are 31 countries in Asia Pacific, not including 3 dependencies, namely Taiwan, Hong Kong, and Macau. The population in Asia represents 60 per cent of the Earth population, it was at 3.978 billion back in 2016.

Several empirical studies have assessed the relationship between public debt and private consumption, finding that testing of the Ricardian equivalence proposition has rather mixed results. The research conducted by (Gogas et al., 2014) aimed to investigate the long-term relationship between public debt and 
private consumption so that to test the potential effectiveness of the Ricardian equivalence proposition. They uses VAR and VEC model as well as Johansen multivariate cointegration tests. The study empirically denied the validity of the proposition of Ricardian equivalence for all the countries in the long term, as the means of public debt in the long run will affect the change in use of the private sector. In contrast, Becker (1995) discriminated between Ricardian and non-Ricardian behaviour and utilised the method distinguishing between expected and unexpected, as well as permanent and transitory changes in taxes and government consumption. Their research model was a VAR with cointegrating constraints and the study sample was all US data. The study empirically supported the Ricardian equivalence proposition, but there were also some deviations from the predictions.

Till today there are some gaps in studying the relationship between public debt and private consumption, such as the use of variables in determining the relationship and findings. In addition, many past studies were done on the OECD countries where the financial system is already developed, see (Gogas, Plakandaras \& Papadimitriou, 2014; Castro and Fernandez, 2013; Fournier and Fall, 2017). In addition, it is unclear how to respond if the country's financial system is not yet so advanced as the ones of many Asia Pacific countries in general. Therefore, this study puts emphasis on the question whether Ricardian equivalence exists in diversified financial systems such as those of Asia Pacific countries. Previous studies in Asia Pacific region on the issues of public debt and private expenditures have been very scarce because most of these studies have focused on how public debt and government spending impacts on economic growth (Khalid, 1996). In the event of fluctuations in government financial resources influencing government spending, the monetary policy will have its impact on public debt rate fluctuations. The next question is about the response from the commodities market. Public debt seems inevitable with the current economic development under the conditions of limited financial sources and the existence of tax restrains due to political or economic reasons.

The rest of the article is organized as follows: 2) Literature review focuses on Ricardian equivalence discussion; 3) Methodology, data sources, definition of variables, specification model and dynamic panel data analysis are presented next. 4) Results and discussion follow and lastly, 5) Conclusions and implications finalize our study.

\section{LITERATURE REVIEW}

Traditional macroeconomics theory states that stabilization policies affect macroeconomic variables. If the government intends to increase the output or reduce unemployment, the government can reduce taxes, increasing disposable income and consumption, and therefore aggregate demand. Still, when resources are fully utilised or are at full capacity, the consequence is an increase in aggregate demand; money demand increases, interest rates increase, investment decreases and, finally, total aggregate demand falls. This is the macroeconomic mechanism known as the 'crowding-out' process worked (Khalid 1996).

The relationship between public debt and private consumption, firstly based on the basic idea introduced by Ricardo, later came to be known as the Ricardian equivalence proposition, even though the formal formulation was first introduced by Barro in 1974. This concept states that increasing public debt ratio at present will not increase the private consumption because the rational consumer expects the government to increase tax in the future. Here, the consumer will save the increase of income as interest rate equivalent with the increased taxes. Unfortunately, empirical studies such as (Gogas et al., 2014) return mixed evidence, with some supporting the proposition, and others only in the long term or in the short term.

In addition, in modern macroeconomics the Ricardian equivalence proposition differently stated when governments try to stimulate the economy by increasing spending through debt financing, consumption 
demand would not change. People respond rationally by saving extra cash to pay for the expected increase in future taxes that will be used to pay debts. In other words, the current tax reduce will be followed by increase in government deficit, (Richardo, 1817) and (Barro, 1974).

Empirical results from several studies have not lent strong support to this theory. Although some studies, such as (Barro, 1978), (Seater and Marion, 1985), (Becker (1995) and (Reitschuler; 2008) have supported Ricardian equivalence proposition, many others found no evidence (Reiter, 1997), and (Castro and Fernandez, 2013) and (Gogas et al; 2014). Such empirical evidence is important due to the implication of policy, and surprisingly the selection of policy should consider infrastructure, level economic system, and financial system, in order to evaluate the response of economic agents and transition of policies.

Related to these contradictory findings, Khalid (1996) analyses the failure of Ricardian equivalence proposition, finding that it can be explained by different econometric models, sample periods, different variables and measurements of those variables, as well as different countries with different economic activity levels and financial systems. In addition, differences of these results may not be met in some of the background assumptions of Ricardian Equivalence 1) Utility - single horizon 2) Rational economic agent 3) perfect capital market, 4) Taxes are not distorted (Barro, 1974). Becker (1995) stated that the assumption of a single horizon and perfect capital are not rational. Another important aspect in that the empirical model utilised by some researchers is based on a lack of explicit theoretical concepts. Like ad hoc empirical models as a reduced form, there is no theoretical and flow argument on the empirical model. Here Michel and Thibaulth (2007) approved theoretically the failure of Ricardian Equivalence under the relaxation of the assumption under dynastic altruism.

Karras (1994) studied the relationship between private consumption and government spending for a number of selected countries from 1950 until 1987. The findings indicate that private consumption and government spending are complementary where the increase in government spending has the potential to improve the marginal private consumption. Becker (1995) argued that the analysis of fiscal policy should take into account the expected and unexpected, as well as permanent and transitory changes in taxes and government consumption. His finding, that there is some support for the Ricardian hypothesis, is contrasted with some deviations from its predictions. However, the differences do not lend support to a Keynesian view of budget deficits, but rather to the view of expansionary fiscal to contractions.

In the early 21st century, Berben and Brosens (2005) found in OECD countries the relationship between private consumption and government debt is non-linear. In addition, for countries whose debt levels are low, public debt does not affect private consumption. In contrast, countries with high debt levels of government debt tend to have a significant negative impact on private consumption. In other words, high debt levels lead to the implementation of fiscal policies less effective in stabilizing fluctuations in the business cycle. In line with stabilizing policy and business cycle in the interaction household, firms and governments based on neoclassical model, Linnemann (2006) indicates that with the occurrence of cyclical changes of government, household tend to respond positively to private consumption. One challenge to the theory of a representative's agency optimization as a source of wealth is that it will negatively affect high fiscal spending, in turn leading to reduced household spending. This can happen if the increase in public debt and investment in production results in higher returns from increased taxes or a minimum amount of risk-free rate of return.

Coccia (2017) supported the asymmetric relationship between public debt and government deficit within and outside unification of the European monetary establishment. Public debt increases when budget deficits increase, compared to countries outside the EMU, and as a consequence the taxes also increase. Implicitly, public debt increase will cause a debt burden and interest increases, and the rational agent will expect tax to increase in the future and reduce income and wealth. Furthermore, the market or economic agent will react to the sustainability of debt, namely for a certain limit of public debt the market will assess 
in terms of the default risk and primary balance insufficient to support rising debt at a high debt level. This is followed by market interest rate reaction for possibility default risk increase to determine the government debt limit beyond the outstanding debt. Finally, the fiscal policy is not potentially effective due to the narrow space of fiscal policy itself (Fournir \& Fall, 2017).

In addition, Paret (2017), using a probabilistic approach for simulation of medium-term public debt of emerging countries with emphasis on the difference cyclical fiscal policies, took into account the additional risk of the external debt. The results made three recommendations i) a country should consider decreasing its exposure to currency risk only in extreme cases; ii) on the contrary, greater fiscal responsiveness (i.e. stronger fiscal tightening whenever there is a debt increase) could enhance sustainability to a much greater extent; iii) responsiveness to countries with low debt or a poor track record of fiscal consolidation should be cautious with countercyclical fiscal policies, as they may trigger an unsustainable debt trajectory in the trough of the economic cycle.

Although the literature has delivered somewhat mixed results, the majority reject the Keynesian approach. The RE proposition states that for a certain path of government expenditure, the timing of taxes should not affect the consumption decisions made by individual taxpayers. The simple idea behind the proposition is that substituting taxes today with tax payment plus interest for tomorrow, via debt financing, does not affect the wealth of individuals. Previous studies, mostly in developed financial systems, support the Ricardian eequivalence proposition, but the relation of public debt in Asia Pacific countries varies considering the weak earlier dynamic panel, linear to nonlinear, and individual countries. It is hoped that this study can describe the relationship of public debt and private consumption in more detail.

\section{RESEARCH METHODOLOGY}

This study that takes Asia Pacific countries as a sample for several years, aiming to observe the impression of the level of economic activity and especially the relationship between public debt and private consumption. Since, the data characteristics consist of Asia Pacific countries and several years, the research intend to analyse the dynamic or endogeneity factor of variable then the model specification is dynamic panel data analysis. Model panel data analysis can be defined with combination of time series data and crosssectional data.

Shortly, private consumption depends on total income, price of domestic commodities (inflation), financing cost for credit purchases (real interest rate), government consumption, government debt and budget deficit as well. In this study, the Ricardian equivalence proposition will be tested through the standard approach from Keynesian economics, a consolidated approach from Ricardian economics, and uncertainty model from Blanchard. The standard approach assumes that private sectors did not take into account government spending into their consumption decision, and the opposite in a consolidated approach.

\section{Mean and Pooled Mean Group}

Standard panel data analysis is not appropriate for macro dynamic panel data because the asymptotes are different from the asymptotes of micro dynamic panels. In addition, the basic standard of panel data assumes that at least some of the parameters are the same across the panel or otherwise the model can arise bias in both static and dynamic panels. In line with this issue, Pesaran and Smith (1995) argued that the traditional panel data analysis can produce inconsistent and potentially very misleading estimates of the average value of the parameters in dynamic panel data model unless the slopes of coefficients are in fact identical.

The important issue of the macro panel is the existence of heterogeneous panel data, in other words some parameters actually vary across the panel. Therefore, the assumption of homogeneity of parameters 
is often inappropriate due to non-stationary and parameters are heterogeneous across group. To overcome these issues, Pesaran and Smith (1995) and Pesaran et el. (1999) suggest different estimators, namely mean group estimator and pooled mean group estimator.

The MG estimator derives the long-run parameters for the panel from an average of the long-run parameters from autoregressive distribution lag (ARDL) model for individual countries (Pesaran and Smith, 1995) is as follows;

$$
Y_{i t}=a_{i}+\gamma_{i} Y_{i t-1}+\beta_{i t} X_{i t}+u_{i t}
$$

where for country $i=1,2, \ldots \ldots . .$. . The long run parameter $\theta_{i}$ for country $i$ is:

$$
\theta_{i}=\frac{\beta_{i}}{1-\gamma_{i}}
$$

and the MG estimators for the whole pale will be given by

$$
\hat{\theta}=\frac{1}{N} \sum_{i=1}^{N} \theta_{i} \quad \hat{a}=\frac{1}{N} \sum_{i=1}^{N} a_{i}
$$

Meanwhile, pooled mean group allows for intercepts, short run coefficients and error term variances to differ freely across groups, but constrains long-run coefficients to be similar across groups (Pesaran, Shin and Smith, 1999). The argument to expect the long run equilibrium relationships between variables to be similar across ground is the infrastructure of economy such as budget constraints, common technologies, and arbitrage condition are almost equal.

The unrestricted specification of the ARDL system then can written by the following equations:

$$
y_{i t}=\sum_{j=1}^{p} \lambda_{i j} y_{i, t-j}+\sum_{j=1}^{q} \gamma_{i j} x_{i, t-j}+\mu_{i}+\varepsilon_{i t}
$$

where $\mathrm{t}=1,2, \ldots . \mathrm{T}$ are time periods, $\mathrm{I}=1,2 \ldots \mathrm{N}$ are countries for the dependent variable $\mathrm{y}, x_{i, t-j}$ is the $(\mathrm{kx} 1)$ vector of explanatory variable for group I and ui is fixed effect. The model can be reparametrized as a VECM system:

$$
\Delta y_{i t}=\theta_{i}\left(y_{i, t-1}-\beta_{i}^{\prime} x_{i, t-1}\right)+\sum_{j=1}^{p-1} \lambda_{i j} \Delta y_{i, t-j}+\sum_{j=1}^{q-1} \gamma_{i j} \Delta x_{i, t-j}+\mu_{i}+\varepsilon_{i t}
$$

where the $\beta_{i}$ are the long-run parameters and $\theta_{i}$ are the equilibrium (or error) correction parameters. Therefore, the PMG restriction is that the elements of $\beta$ are common across countries is as follow.

$$
\Delta y_{i t}=\theta_{i}\left(y_{i, t-1}-\beta^{\prime} x_{i, t-1}\right)+\sum_{j=1}^{p-1} \lambda_{i j} \Delta y_{i, t-j}+\sum_{j=1}^{q-1} \gamma_{i j} \Delta x_{i, t-j}+\mu_{i}+\varepsilon_{i t}
$$

Both MG and PMG estimations require selecting the appropriate lag length for individual country equation. To examine the hypothesis of homogeneity of the long run policy parameters is an implied the effect of heterogeneity of coefficients determined by a Hausman-type test (Hausman, 1978). If the parameters are homogeneous, the PMG estimates are more efficient than MG. Conversely, under the null hypothesis, the difference in the estimated coefficients between the MG and PMG are not significantly different. Conclusion is PMG is more efficient. 


\section{Dynamic Fixed Effect (DFE)}

In this case, individual country specific effects are controlled for. The DFE estimator is like the PMG, in that it imposes homogeneity of all slope coefficients, allowing only the intercept to vary across countries. Then, it further restricts the speed of adjustment coefficient and the short run coefficients to be equal.

According to Castro and Fernández (2013), and Ghatak and Ghatak (1996) the Ricardian equivalence proposition might be tested through standard approach from the Keynesian, consolidated approach and uncertainty model of (Blanchard, 1985) as well. The standard approach assumes that private sectors did not take into account the government spending into their consumption decision, and the opposite in consolidated approach.

In this study, PC is the private consumption and can be explained by disposable income (YD), public debt (PD), budget deficit (BD), and household wealth, capital accumulation (CF) is known as the traditional model with separated public debt and budget equation.

$$
\begin{aligned}
& P C_{i t}=\theta_{0 \mathrm{t}}+\theta_{1} P D_{i t}+\theta_{2} Y D_{i t}+\theta_{3} C F_{i t}+\mu_{i}+\epsilon_{i t} \\
& P C_{i t}=\theta_{0 \mathrm{t}}+\theta_{1} B D_{i t}+\theta_{2} Y D_{i t}+\theta_{3} C F_{i t}+\mu_{i}+\epsilon_{i t}
\end{aligned}
$$

The above model then can be extended into a more general model adopted from Kemeli (1997) and Gogas et al, (2014) because it is tested based on the Keynesian approach, implying that it is not only to test Ricardian equivalence. The extended model includes the PD and BD in one equation and includes and government consumption (GC). Then, the empirical long run private consumption function can be equated as follows;

$$
P C_{i t}=\theta_{0 \mathrm{t}}+\theta_{1} P D_{i t}+\theta_{2} B D_{i t}+\theta_{3} Y D_{i t}+\theta_{4} G C_{i t}+\theta_{5} I R_{i t}+\theta_{6} R I R_{i t}+\mu_{i}+\epsilon_{i t}
$$

Where the number of nations $i=1,2 \ldots . \mathrm{N}$; the number of periods $t=1,2, \ldots . \mathrm{T} ; \mathrm{c}_{\mathrm{it}}$ is the private consumption; $\mathrm{pd}_{\mathrm{it}}$ is public debt; $\mathrm{bd}_{\mathrm{it}}$ is budget deficit; $\mathrm{gc}_{\mathrm{it}}$ is government consumption; $\mathrm{yd}_{\mathrm{it}}$ is income per capita, ${ } r_{i t}$ is inflation rate and rir $_{i t}$ is real interest rate. If PD is significant, the results state that there is no neutrality of public debt or Ricardian equivalence is not held. This is because the economic agents or households consider public debt as a net wealth. The same rational argument with budget deficit. In addition, Blanchard (1985) argued that traditional model cannot address the appropriate the Ricardian equivalence. Therefore, he developed a model based on consumption function, budget constraint to maximize the consumption. The model to test the neutrality hypothesis is based on uncertainty model. The current consumption is a function of the value of last year's asset stock and present value of expected labour income in future.

Where the number of nations $i=1,2 \ldots \mathrm{N}$; the number of periods $t=1,2, T$; $c_{i t}$ is the private consumption; $\mathrm{pd}_{\mathrm{it}}$ is public debt; $\mathrm{yd}_{\mathrm{it}}$ is income per capita; $\mathrm{cf}_{\mathrm{it}}$ is capital accumulation, $\mathrm{gc}_{\mathrm{it}}$ is government expenditure, ${ }_{i} r_{i t}$ is inflation rate and rir $_{i t}$ is real interest rate.

The equation 7-10, if the variables are $I(1)$ and cointegrated, then the error term is $I(0)$ for all $i$. The ARDL 1,1,1 or 1,1,1,1,1 dynamic panel specification of equation (7-10) is as follows:

$$
\begin{aligned}
& C_{i t}=\gamma_{10 \mathrm{i}} \mathrm{P} D_{i t}+\gamma_{11 \mathrm{i}} P D_{i t-1}+\gamma_{20 \mathrm{i}} Y D_{i t}+\gamma_{21 \mathrm{i}} Y D_{i t-1}+\gamma_{30 \mathrm{i}} C F_{i t}+\gamma_{31 \mathrm{i}} C F_{i t-1}+\lambda_{i C i t-1} \mu_{i}+\epsilon_{i t} \\
& C_{i t}=\gamma_{10 \mathrm{i}} B D_{i t}+\gamma_{11 \mathrm{i}} B D_{i t-1}+\gamma_{20 \mathrm{i}} Y D_{i t}+\gamma_{21 \mathrm{i}} Y D_{i t-1}+\gamma_{30 \mathrm{i}} C F_{i t}+\gamma_{31 \mathrm{i}} C F_{i t-1}+{ }_{\lambda i C i t-1} \mu_{i}+\epsilon_{i t} \\
& C_{i t}=\gamma_{10 \mathrm{i}} P D_{i t}+\gamma_{11 \mathrm{i}} P D_{i t-1}+\gamma_{20 \mathrm{i}} B D_{i t}+\gamma_{21 \mathrm{i}} B D_{i t-1}+\gamma_{30 \mathrm{i}} Y D_{i t}+\gamma_{31 \mathrm{i}} Y D_{i t-1}+\gamma_{40 \mathrm{i}} G C_{i t}+\gamma_{41 \mathrm{i}} G C_{i t-1} \\
& +\gamma_{50 i} I R_{i t}+\gamma_{51 \mathrm{i}} I R_{i t-1}+\gamma_{60 i \mathrm{i}} \mathrm{RIR} \mathrm{R}_{i t}+\gamma_{61 \mathrm{i}} \mathrm{RIR} \mathrm{R}_{i t-1}+{ }_{\lambda_{i} i \mathrm{it}-1} \mu_{i}+\epsilon_{i t}
\end{aligned}
$$

The error correction reparameterization of equations (10-12) are;

$$
\begin{aligned}
& \Delta C_{i t}=\varphi_{\mathrm{i}}\left(C_{i, t-1}-\theta_{0 \mathrm{i}}-\theta_{1 \mathrm{i}} P D_{i t}-\theta_{2 \mathrm{i}} Y D_{i t}-\theta_{3 \mathrm{i}} C F_{i t}\right)+\gamma_{11 \mathrm{i}} \Delta P D_{i t}+\gamma_{21 \mathrm{i}} \Delta Y D_{i t}+\gamma_{31 \mathrm{i}} \Delta C F_{i t}+\epsilon_{i t} \\
& \Delta C_{i t}=\varphi_{\mathrm{i}}\left(C_{i, t-1}-\theta_{0 \mathrm{i}}-\theta_{1 \mathrm{i}} B D_{i t}-\theta_{2 \mathrm{i}} Y D_{i t}-\theta_{3 \mathrm{i}} C F_{i t}\right)+\gamma_{11 \mathrm{i}} \Delta B D_{i t}+\gamma_{21 \mathrm{i}} \Delta Y D_{i t}+\gamma_{31 \mathrm{i}} \Delta C F_{i t}+\epsilon_{i t} \\
& \Delta C_{i t}=\varphi_{\mathrm{i}}\left(C_{i, t-1}-\theta_{0 \mathrm{i}}-\theta_{1 \mathrm{i}} P D_{i t}-\theta_{2 \mathrm{i}} B D_{i t}-\theta_{3 \mathrm{i}} Y D_{i t}-\theta_{4 \mathrm{i}} G C_{i t}-\theta_{5 \mathrm{I}} I R_{i t}-\theta_{6 \mathrm{i}} R I R_{i t}\right)+\gamma_{11 \mathrm{i}} \Delta P D_{i t}+
\end{aligned}
$$


$\gamma_{21 i} \Delta B D_{i t}+\gamma_{31 i} \Delta Y D_{i t}+\gamma_{41 i} \Delta G C_{i t}+\gamma_{511} \Delta I R_{i t}+\gamma_{61 i} \Delta R I R_{t}+\epsilon_{i t}$

Where; $\varphi \mathrm{i}=-\left(1-\lambda_{i}\right), \theta_{0 \mathrm{i}}=\mu i /\left(1-\lambda_{i}\right), \theta_{\mathrm{it}}=\left(\gamma_{10 \mathrm{i}}+\gamma_{11 \mathrm{i}}\right) /\left(1-\lambda_{i}\right) \ldots \ldots \ldots\left(\gamma_{90 \mathrm{i}}+\gamma_{91 \mathrm{i}}\right) /\left(1-\lambda_{i}\right)$.

Theoretically, we expect that coefficient of $c_{t-1}$ significant and close to unity if $c_{t}$ follows a random path. If the agents are faced with liquid constraint then the lag of income should be significant to $c_{t}$. A reduced form equation states that $c_{t}$ function on its own lag and lag disposable income and government spending as well. Full Ricardian equivalence assumes an infinite horizon and no liquidity constraint. Liquidity $\operatorname{con} \theta$, no liquidity equal 0 , infinite life so $\gamma=1, c_{t}$ just function on $c_{t-1}$ and degree of substitute $\mathrm{c}$ and $\mathrm{g}$ if $\sigma=0$ no substitute.

The error-correction speed of adjustment parameter is $\varphi \mathrm{i}$ and the long run coefficients are $\theta_{1 \mathrm{i}}, \theta_{2 \mathrm{i}}, \theta_{8 \mathrm{i}}$, $\theta_{9 \mathrm{j}}$, these are the primary interest. With the inclusion of $\theta_{0 \mathrm{i}}$ is a nonzero mean of the cointegrating relationship is allowed. Then value $\varphi \mathrm{i}$ would be expected to be negative if the variables declare a return to long run equilibrium.

\section{Research Variables and Data Sources}

In this study, there are main variables; private consumption, public debt, budget deficit, income per capita, capital accumulation, inflation rate and real interest rate. Private consumption is total household final consumption at 2013/14 market price. Public debt is total public debt and publicly guaranteed in million US dollar. Per capita income is per capita GDP. Inflation is the GDP deflator, and government consumption is the general government final consumption. Budget deficit is overall budgetary surplus/deficit percent of GDP at current market prices. Population is total population in millions. Real interest rate is the semiannually interest for the saving and adjusted with inflation. All data were collected from Asian Development Bank, over 28 years starting year 1990 to year 2017. The sample is 18 countries based the availability and completeness of data. Detail of 18 countries is as follow; Bangladesh, Bhutan, Nepal, Sri Lanka, Pakistan, India, South Korea, Japan, Taiwan, China, Indonesia, Philippines, Malaysia, Thailand, Vietnam, Australia, Fiji, and New Zealand. This list comprises several levels of developed countries, developing countries, and undeveloped countries.

\section{RESULTS AND DISCUSSION}

These results are based on 18 Asia Pacific countries, in the period 1990-2017 from various levels of financial development. This research investigates the relationship between public debt and private consumption in the both long-term, short-term and speed of convergence. Data are converted to the natural logarithm of private consumption, public debt, government consumption, budget balance and gross domestic product. All are in real terms and per capita. We used MG, PMG and DFE specification model because they are well-suited with our objective and the characteristic data which differ in terms of variability of country. PMG and MG impose parameters of long-run homogeneity for all slope coefficients but the intercept, short-run adjustment and convergence speed may vary across country. However, DFE is imposing the long-run homogeneity restriction of all slope coefficient but the intercept only varies across countries.

Table 1 shows the results of equation 7 and by considering the appropriate lag length for individual countries based on BIC and AIC test, we have the ARDL $(1,1,1)$ for all countries. PMG, MG and DFE specification results indicate an error-correct effect or convergence speed is negatively significant and suitable with model specification requirement which should have negatively sign. It is implied that the longrun relationship between dependent variable and independent variable is stable and convergent. In addition, results show that significant variation of private consumption depend on the estimation method used. For example, the speed of convergence for PMG is highest compare to the other then followed by MG and 
DFE results for both models. There is significant support for the hypothesis that long-run homogeneity exists, because Hausman test could not reject the homogeneity restriction assumption therefore PMG model is the preferred model. Accordingly, the long-run coefficients are identical across the countries of Asia Pacific.

The traditional approach is where private consumption is presented by public debt, income and total capital accumulation. The results state that in the long-run, public debt negatively affects PMG and MG in private consumption for model 1. In model 2, the long-run public debt has no effect on for PMG and MG in private consumption, and it has a significant effect at 10-percent for DFE. These results do not offer strong support for the Ricardian equivalence proposition. Also, total capital accumulation and disposable income have a positive effect on private consumption with the lowest mitigating effect in the PMG model and the highest mitigating effect in DFE model. Therefore, the variability of private consumption is more affected by household wealth and sources from fiscal policy through public debt.

Table 1

Estimation results of the dynamic panel model (ARDL 1,1,1)

Dependent variable Ln PC

\begin{tabular}{|c|c|c|c|c|c|c|}
\hline Model & \multicolumn{2}{|c|}{ PMG } & \multicolumn{2}{|c|}{ MG } & \multicolumn{2}{|c|}{ DFE } \\
\hline & I & II & I & II & I & II \\
\hline \multicolumn{7}{|c|}{ Long-run coefficient } \\
\hline Ln PD & $\begin{array}{c}-0.072^{* * *} \\
(0.016)\end{array}$ & $\begin{array}{c}0.008 \\
(0.009)\end{array}$ & $\begin{array}{c}0.107 \\
(0.094)\end{array}$ & $\begin{array}{c}0.405 \\
(0.296)\end{array}$ & $\begin{array}{c}0.023 \\
(0.022)\end{array}$ & $\begin{array}{l}0.070^{*} \\
(0.041)\end{array}$ \\
\hline Ln YD & $\begin{array}{c}0.986^{* * *} \\
(0.005)\end{array}$ & & $\begin{array}{l}1.514^{* *} \\
(0.608)\end{array}$ & & $\begin{array}{c}0.958^{* * *} \\
(0.017)\end{array}$ & \\
\hline$\Delta \mathrm{Ln} C F$ & & $\begin{array}{c}0.768^{* * *} \\
(0.011)\end{array}$ & & $\begin{array}{c}0.730^{* * *} \\
(0.097)\end{array}$ & & $\begin{array}{c}0.831 \text { *** } \\
(0.031)\end{array}$ \\
\hline Error-correction effect & $\begin{array}{c}-0.192^{* * *} \\
(0.054)\end{array}$ & $\begin{array}{c}-0.152^{* * *} \\
(0.031)\end{array}$ & $\begin{array}{c}-0.370 * * * \\
(0.046)\end{array}$ & $\begin{array}{c}-0.215^{* * *} \\
(0.040)\end{array}$ & $\begin{array}{c}-0.252^{* * *} \\
(0.031)\end{array}$ & $\begin{array}{c}0.220^{* * *} \\
(0.025)\end{array}$ \\
\hline \multicolumn{7}{|c|}{ Short-run coefficient } \\
\hline$\Delta \mathrm{Ln} P \mathrm{PD}$ & $\begin{array}{c}0.090^{* * *} \\
(0.031)\end{array}$ & $\begin{array}{c}0.207 * * * \\
(0.052)\end{array}$ & $\begin{array}{c}0.096^{* * *} \\
(0.031)\end{array}$ & $\begin{array}{c}0.168^{* * *} \\
(0.041)\end{array}$ & $\begin{array}{c}0.015 \\
(0.013)\end{array}$ & $\begin{array}{c}0.135^{* * * *} \\
(0.021)\end{array}$ \\
\hline$\Delta \operatorname{Ln} Y D$ & $\begin{array}{c}0.550^{* * *} \\
(0.095)\end{array}$ & & $\begin{array}{c}0.384^{* * *} \\
(0.094)\end{array}$ & & $\begin{array}{c}0.697 * * * \\
(0.042) \\
\end{array}$ & \\
\hline$\Delta \mathrm{Ln} C F$ & & $\begin{array}{c}0.019 \\
(0.083) \\
\end{array}$ & & $\begin{array}{l}-0.004 \\
(0.083) \\
\end{array}$ & & $\begin{array}{l}-0.056 \\
(0.044) \\
\end{array}$ \\
\hline Const & $\begin{array}{l}0.050^{* *} \\
(0.024)\end{array}$ & $\begin{array}{c}0.368^{* * *} \\
(0.066)\end{array}$ & $\begin{array}{c}0.065 \\
(0.120)\end{array}$ & $\begin{array}{l}0.331^{*} \\
(0.189)\end{array}$ & & $\begin{array}{c}0.365^{* * *} \\
(0.058)\end{array}$ \\
\hline Max log likehood & 1088.119 & 885.050 & & & & \\
\hline Hausman test & $\begin{array}{c}4.68 \\
(0.096)\end{array}$ & $\begin{array}{c}1.59 \\
(0.452)\end{array}$ & & & & \\
\hline No of countries & 18 & 18 & 18 & 18 & 18 & 18 \\
\hline No of obs. & 486 & 486 & 486 & 486 & 486 & 486 \\
\hline
\end{tabular}

Notes: The parenthesis (.) is standard deviation. ${ }^{* * *}$ denotes significance at the $1 \%$.

** denotes significance at the $5 \%$.* denotes significance at the $10 \%$. 
In the short-run, the results show that public debt, total wealth presented by capital accumulation and disposable income have a positive and significant influence on private consumption. This implies that in the short-run, public debt and government expenditure increase which would affect the aggregate output to increase household income and private consumption. Inversely, in the long-run, public debt increases and households expect the government will increase tax in the long-run, disponssible decrease and fllowed by reducing private consumption. Also, if the total income increases, so too will household expenditure in the short- and long-run. However, if capital accumulation increases, then private consumption increases in the long-run only, because, rationally, capital accumulations are invested in long-term investment instruments.

Table 2 shows the results of equation 8 and by considering the appropriate lag length for individual countries based on BIC and AIC test, we have the ARDL $(1,1,1)$ for all countries. PMG, MG and DFE specification results indicate the error-correct effect or convergence speed is negatively significant and suitable with model specification requirement which should have a negative sign. It is implied that the long run relationship between dependent variable and independent variable occurs. In addition, findings show that significant variation of private consumption depends on the estimation method used. For example, the speed of convergence for PMG is highest compared to others then followed by MG and DFE results for both models. There is significant support for the hypothesis that long-run homogeneity exists because Hausman test could not reject the homogeneity restriction, therefore PMG model is preferred model, concluded the long-run coefficients are still identical across countries of Asia Pacific.

Estimation results of the dynamic panel model (ARDL 1, 1, 1)

Dependent variable Ln PC

\begin{tabular}{|c|c|c|c|c|c|c|}
\hline & \multicolumn{2}{|c|}{ PMG } & \multicolumn{2}{|c|}{$\mathrm{MG}$} & \multicolumn{2}{|c|}{ DFE } \\
\hline \multicolumn{2}{|c|}{ Long-run coefficient } & & & & & \\
\hline Ln BD & $\begin{array}{l}-0.017^{*} \\
(0.010)\end{array}$ & $\begin{array}{l}0.421^{*} \\
(0.250)\end{array}$ & $\begin{array}{l}-1.365 \\
(1.923)\end{array}$ & $\begin{array}{c}-10.491 \\
(8.246)\end{array}$ & $\begin{array}{c}0.075 \\
(0.055)\end{array}$ & $\begin{array}{c}-0.304^{* * *} \\
(0.083)\end{array}$ \\
\hline Ln YD & $\begin{array}{c}0.995^{* * *} \\
(0.007)\end{array}$ & & $\begin{array}{c}0.850 * * * \\
(0.139)\end{array}$ & & $\begin{array}{c}0.952^{* * *} \\
(0.018)\end{array}$ & \\
\hline Ln CF & & $\begin{array}{c}0.856^{* * *} \\
(0.033)\end{array}$ & & $\begin{array}{l}-0.602 \\
(1.088)\end{array}$ & & $\begin{array}{c}0.815^{* * *} \\
(0.026)\end{array}$ \\
\hline Error-correction effect & $\begin{array}{c}-0.251 * * * \\
(0.045)\end{array}$ & $\begin{array}{c}-0.178^{* * *} \\
(0.039)\end{array}$ & $\begin{array}{c}-0.389 * * * \\
(0.047)\end{array}$ & $\begin{array}{c}-0.404 * * * \\
(0.070)\end{array}$ & $\begin{array}{c}-0.260 * * * \\
(0.032)\end{array}$ & $\begin{array}{c}-0.284 * * * \\
(0.028)\end{array}$ \\
\hline \multicolumn{2}{|c|}{ Short-run coefficient } & & & & & \\
\hline$\Delta \mathrm{Ln} B D$ & $\begin{array}{l}-0.717 \\
(0.735)\end{array}$ & $\begin{array}{l}-0.480 \\
(1.016)\end{array}$ & $\begin{array}{c}0.742 \\
(0.507)\end{array}$ & $\begin{array}{c}0.300 \\
(1.802)\end{array}$ & $\begin{array}{c}0.016 \\
(0.017)\end{array}$ & $\begin{array}{l}0.055^{*} \\
(0.029)\end{array}$ \\
\hline$\Delta \operatorname{Ln~YD}$ & $\begin{array}{c}0.559 * * * \\
(0.073)\end{array}$ & & $\begin{array}{c}0.445^{* * *} \\
(0.084)\end{array}$ & & $\begin{array}{c}0.705^{* * *} \\
(0.042)\end{array}$ & \\
\hline$\Delta \operatorname{Ln} C F$ & & $\begin{array}{l}-0.141 \\
(0.179)\end{array}$ & & $\begin{array}{l}-0.197 \\
(0.193)\end{array}$ & & $\begin{array}{c}-0.127 * * * \\
(0.045)\end{array}$ \\
\hline Const & $\begin{array}{c}-0.028^{*} \\
(0.015)\end{array}$ & $\begin{array}{c}-0.378^{* * *} \\
(0.091)\end{array}$ & $\begin{array}{l}-1.780 \\
(3.423)\end{array}$ & $\begin{array}{c}13.562^{* *} \\
(5.426)\end{array}$ & $\begin{array}{c}0.190 \\
(0.172)\end{array}$ & $\begin{array}{c}1.489 * * * \\
(0.302)\end{array}$ \\
\hline Max log likehood & 1086.008 & 841.028 & & & & \\
\hline Hausman test & $\begin{array}{c}0.93 \\
(0.628)\end{array}$ & $\begin{array}{c}1.100 \\
(0.577)\end{array}$ & & & & \\
\hline No of countries & 18 & 18 & 18 & 18 & 18 & 18 \\
\hline No of obs. & 486 & 486 & 486 & 486 & 486 & 486 \\
\hline
\end{tabular}

Notes: The parenthesis (.) is standard deviation. *** denotes significance at the $1 \%$.

** denotes significance at the $5 \%$. * denotes significance at the $10 \%$. 
The traditional approach is where private consumption is presented by government deficit, income and capital accumulation. The result states that in the long-run, the budget deficit could affect private consumption for the both models but with different signs. These results do not offer strong support for the Ricardian equivalence proposition. Nevertheless, total capital accumulation and disposable income have a positive effect on private consumption with the lowest mitigating effect in the PMG model and the highest mitigating effect for DFE in both models. Therefore, the variability of private consumption is affected by household wealth and sources from fiscal policy about the choice between raising tax and debt financing. However, in the short-run, the results state conversely that the budget deficit and total capital accumulation do not significantly influence private consumption, while income has a positively significant influence on private consumption. Therefore, private consumption in the Asia Pacific is generated more by human income compared to the fiscal policy considerations in the short-run.

Table 3 indicates that three model PMG, MG and DFE have the long-run co-integrated relationship between the budget deficits or public debt, disposable income, government expenditure, inflation rate and real interest rate and private consumption as shown by the error-correction effect (coefficient) are negative and statistically significant. In addition, results show that significant variation of private consumption depending on the estimation method used. For example, the speed of convergence for PMG is highest compared to others, then followed by DFE and MG results. There is significant support for the hypothesis that long-run homogeneity exists because Hausman test could not reject the homogeneity restriction assumption, therefore PMG is the preferred model, and therefore the long-run coefficients are still identical across countries of Asia Pacific.

In the general approach, private consumption is affected by disposable income, government expenditure, inflation rate, real interest rate, public debt or the budget deficit. The results state that, in the long-run, public debt does not affect private consumption for models PMG and DFE, and a significant effect at 10 percent for MG. Also, the budget deficit has no effect on private consumption for all models (PMG, MG and DFE). Consequently, Asia Pacific countries strongly support the Ricardian equivalence proposition where the financing of budget deficit does not affect private consumption. This means that if the government finances the budget deficit by increasing public debt, household will respond with raising saving from the expected of income raise then private consumption unchanged. In addition disposable income and government expenditure positively affect private consumption. Implied that when income and government spending increase, then private consumption will increase significantly. Lastly, inflation rate and real interest rate positively affect private consumption. In other words, when inflation and real interest rate increase, then private consumption will rise significantly. In the short-run, these results also offer strong support for the Ricardian equivalence proposition. The remaining variables of disposable income and government expenditure positively affect private consumption, while inflation rate and real interest rate do not affect private consumption in the short-run.

Overall, the traditional approach indicated that public debt affects private consumption in the longand short-run, while budget deficit affects private consumption in the long-run only. These findings imply that the financing policy of the budget deficit differs from the viewpoints of the private or household sectors. The changes in consumption are affected by their financial assets and fiscal policy through public debt policy. These findings are supported by Reiter (1997), Castro and Fernandez (2013), and Gogas et al. (2014). 
Estimation results of the dynamic panel model ... (ARDL 1, 1, 1, 1, 1)

Dependent variable $\mathrm{Ln}$ PC

\begin{tabular}{|c|c|c|c|c|c|c|}
\hline & \multicolumn{2}{|c|}{ PMG } & \multicolumn{2}{|c|}{$\mathrm{MG}$} & \multicolumn{2}{|c|}{ DFE } \\
\hline \multicolumn{2}{|c|}{ Long-run coefficient } & & & & & \\
\hline Ln YD & $\begin{array}{c}0.950^{* * *} \\
(0.010)\end{array}$ & $\begin{array}{c}0.944 * * * \\
(0.009)\end{array}$ & $\begin{array}{c}0.144 \\
(0.644)\end{array}$ & $\begin{array}{c}0.576 * * \\
(0.249)\end{array}$ & $\begin{array}{c}0.635^{* * *} \\
(0.069)\end{array}$ & $\begin{array}{c}0.463 * * * \\
(0.041)\end{array}$ \\
\hline Ln GC & $\begin{array}{c}0.070 * * * \\
(0.010)\end{array}$ & $\begin{array}{c}0.073 * * * \\
(0.010)\end{array}$ & $\begin{array}{c}0.889 \\
(0.772)\end{array}$ & $\begin{array}{l}-0.204 \\
(0.358)\end{array}$ & $\begin{array}{c}0.328^{* * *} \\
(0.072)\end{array}$ & $\begin{array}{c}0.295^{* * *} \\
(0.029)\end{array}$ \\
\hline Ln IR & $\begin{array}{c}0.010^{* * *} \\
(0.003)\end{array}$ & $\begin{array}{c}0.013 * * * \\
(0.004)\end{array}$ & $\begin{array}{c}0.111 \\
(0.080)\end{array}$ & $\begin{array}{c}0.003 \\
(0.063)\end{array}$ & $\begin{array}{c}0.005 \\
(0.027)\end{array}$ & $\begin{array}{l}-0.002 \\
(0.007)\end{array}$ \\
\hline Ln RIR & $\begin{array}{c}0.017 * * * \\
(0.003)\end{array}$ & $\begin{array}{c}0.012^{* * *} \\
(0.003)\end{array}$ & $\begin{array}{c}0.241 \\
(0.149) \\
\end{array}$ & $\begin{array}{c}0.054 \\
(0.048) \\
\end{array}$ & $\begin{array}{c}0.026 \\
(0.017) \\
\end{array}$ & $\begin{array}{c}0.006 \\
(0.007)\end{array}$ \\
\hline Ln PD & $\begin{array}{l}-0.007 \\
(0.009)\end{array}$ & & $\begin{array}{l}0.203^{*} \\
(0.113)\end{array}$ & & $\begin{array}{c}0.029 \\
(0.021)\end{array}$ & \\
\hline Ln BD & & $\begin{array}{l}-0.003 \\
(0.003)\end{array}$ & & $\begin{array}{l}-6.260 \\
(5.044)\end{array}$ & & $\begin{array}{c}0.012 \\
(0.015)\end{array}$ \\
\hline Error-correction effect & $\begin{array}{c}-0.232 * * * \\
(0.081)\end{array}$ & $\begin{array}{c}-0.232^{* * *} \\
(0.078)\end{array}$ & $\begin{array}{c}-0.456 * * * \\
(0.088)\end{array}$ & $\begin{array}{c}-0.528^{* * *} \\
(0.093)\end{array}$ & $\begin{array}{c}-0.236^{* * *} \\
(0.030)\end{array}$ & $\begin{array}{c}-0.243^{* * *} \\
(0.030)\end{array}$ \\
\hline \multicolumn{2}{|c|}{ Short-run coefficient } & & & & & \\
\hline$\Delta \operatorname{Ln} Y D$ & $\begin{array}{c}0.449 * * * \\
(0.095)\end{array}$ & $\begin{array}{c}0.450 * * * \\
(0.084)\end{array}$ & $\begin{array}{l}0.208^{*} \\
(0.120)\end{array}$ & $\begin{array}{c}0.134 \\
(0.108)\end{array}$ & $\begin{array}{c}0.465^{* * *} \\
(0.041)\end{array}$ & $\begin{array}{c}0.625^{* * *} \\
(0.068)\end{array}$ \\
\hline$\Delta \operatorname{Ln} G C$ & $\begin{array}{c}0.198^{* * *} \\
(0.060)\end{array}$ & $\begin{array}{c}0.181 * * * \\
(0.064)\end{array}$ & $\begin{array}{l}0.091 * \\
(0.050)\end{array}$ & $\begin{array}{c}0.063 \\
(0.058)\end{array}$ & $\begin{array}{c}0.300^{* * *} \\
(0.029)\end{array}$ & $\begin{array}{c}0.333^{* * *} \\
(0.070)\end{array}$ \\
\hline$\Delta \operatorname{Ln} I R$ & $\begin{array}{l}-0.000 \\
(0.010)\end{array}$ & $\begin{array}{l}-0.000 \\
(0.008)\end{array}$ & $\begin{array}{c}-0.029 * * \\
(0.012)\end{array}$ & $\begin{array}{c}-0.035^{* * *} \\
(0.012)\end{array}$ & $\begin{array}{l}-0.001 \\
(0.007)\end{array}$ & $\begin{array}{c}0.004 \\
(0.027)\end{array}$ \\
\hline$\Delta \operatorname{Ln} \mathrm{RIR}$ & $\begin{array}{c}0.006 \\
(0.015)\end{array}$ & $\begin{array}{c}0.010 \\
(0.017)\end{array}$ & $\begin{array}{c}0.007 \\
(0.013)\end{array}$ & $\begin{array}{l}-0.004 \\
(0.013)\end{array}$ & $\begin{array}{c}0.005 \\
(0.007)\end{array}$ & $\begin{array}{c}0.019 \\
(0.016)\end{array}$ \\
\hline$\Delta \operatorname{Ln} \mathrm{PD}$ & $\begin{array}{c}0.021 \\
(0.023)\end{array}$ & & $\begin{array}{c}0.027 \\
(0.023)\end{array}$ & & $\begin{array}{l}-0.001 \\
(0.011)\end{array}$ & \\
\hline$\Delta \mathrm{Ln} \mathrm{BD}$ & & $\begin{array}{l}-0.635 \\
(0.532)\end{array}$ & & $\begin{array}{c}1.221 \\
(0.781)\end{array}$ & & $\begin{array}{l}-0.064 \\
(0.050)\end{array}$ \\
\hline Const & $\begin{array}{c}-0.049 * * * \\
(0.017)\end{array}$ & $\begin{array}{c}-0.058^{* * *} \\
(0.017)\end{array}$ & $\begin{array}{c}0.065 \\
(0.119) \\
\end{array}$ & $\begin{array}{l}-8.434 \\
(6.669) \\
\end{array}$ & $\begin{array}{c}0.070 \\
(0.053)\end{array}$ & $\begin{array}{l}-0.043 \\
(0.040) \\
\end{array}$ \\
\hline Max log likehood & 1219.047 & 1220.196 & & & & \\
\hline Hausman test & $\begin{array}{c}1.88 \\
(0.866)\end{array}$ & $\begin{array}{c}1.74 \\
(0.884)\end{array}$ & & & & \\
\hline No of countries & 18 & 18 & 18 & 18 & 18 & 18 \\
\hline No of obs. & 486 & 486 & 486 & 486 & 486 & 486 \\
\hline
\end{tabular}

Notes: The parenthesis (.) is standard deviation. *** denotes significance at the $1 \%$.

** denotes significance at the $5 \%$. * denotes significance at the $10 \%$.

Unfortunately, the results from the general approach indicated that public debt does not affect private consumption in the long- and short-run. These findings imply that the financing policy of the budget deficit does not differ in the viewpoints of the private and household sectors. The changes in consumption are affected by their household wealth income and capital accumulation and fiscal policy. This means that the Ricardian equivalence exists. These findings are supported by Richardo (1817), Barro (1974), Reitschuler (2008) and Haris and Mohammad (2015). The Ricardian equivalence states that the method of financing the 
budget deficit has no effect on private consumption as the private sector will respond to the financing policy. For example, if the government did not increase the tax to finance deficit but increases public debt, then the private sector expects the government tax to increase in the near future to service the debt. As such, it will save money to support the tax payment in the future for financing the current public deficit or debt.

In addition, disposable income and government expenditure positively affect private consumption in the short- and long-run. These findings imply that, when income increases, private sector consumption will increase. This is supported by the standard concept of marginal propensity to consume. It is also supported by Karras (1994) and Pozzi (2006). When government expenditure increases, then aggregate domestic demand increase as well as aggregate output and income. This will cause private consumption to increase as indicated by Pozzi (2006). Also, capital accumulation positively affects private consumption in the long-run but had no effect in the short-run because capital accumulation is more related to the long-term investment compared to short-run investment. This means the effect on consumption manifests in the long-run as supported by Ghatak and Ghatak (1996). Real interest rate and inflation rate positively affect private consumption in the long-run and not in the short-run. This implies that when real interest rate and inflation rate increase, so too will private consumption due to consumption which depends on the overall effect of the interest rate. In this case, consumption is better than saving as supported by Siew-Voon et al. (2017). When inflation increases implicitly, the real interest rate will reduce (Fisher effect) and consumption will rise as supported by Li et al. (2017)

\section{CONCLUSION AND IMPLICATION}

This article investigates the empirical support for Ricardian equivalence in the long- and short-term relationships between fiscal policy through public debt or government budget deficit and private consumption in 18 Asia Pacific countries focusing on the importance of heterogeneity for empirical results. We impose heterogeneity in the relationship between public debt and private consumption by considering different specification models, i.e., the pooled mean group, mean group and dynamic fixed effect estimator. The PMG estimator permission has a higher degree of heterogeneity among countries than is common in other empirical Ricardian equivalent tests. The PMG estimator considers country-specific effects as usual but also allows the short-run growth responses of each country to vary, imposing only common long-run relationships.

The results for the general approach defend the previous findings that there is no effect between fiscal policy and private consumption in Asia Pacific countries in the long- and short-run. This meaning that the Ricardian equivalence exists. In contrast, results for the traditional approach show that the Ricardian equivalence does not exit. In addition, total capital accumulation as a proxy of household wealth, disposable income and government expenditure has a positive effect on private consumption in the long- and shortterm. However, the inflation rate and real interest rate have a positive effect on private consumption in the long-term only. This is because disposable income, capital accumulation, government expenditure, inflation and real interest rate determine the variability of private consumption in Asia Pacific countries.

In most countries, the increase in government debt, irrespective of financing policy, does not affect private consumption. The major implication of this finding is that governments should balance budgetary efforts across economic activities. Asia Pacific countries should not focus primarily on microeconomic variables to increase private consumption, but also need to pay intention to fiscal policy. Future research could be extended to a longer period and more countries. Also, separate analysis could be performed for each level of financial development and compared. 


\section{REFERENCES}

Barro, R.J. (1974). Are government bonds net wealth, Journal of Political Economy, 82, 1095-1117.

Barro, R.J. (1978). The impact of social security on private saving, American Enterprise Institute Studies, no; 199 (Washington: American Enterprise Institute for Public Policy Research).

Barro, R. J. (1989). The Ricardian approach to budget deficits. Journal of Economic perspectives, 3(2), 37-54.

Becker, T. (1995). Government debt and private consumption: Theory and evidence. Economic Research Institute, Stockholm School of Economics.

Berben, R. P., \& Brosens, T. (2005). The impact of government debt on private consumption in OECD countries. De Nederlandsche Bank Working Paper. Amsterdam, Netherlands.

Blanchard, O. J. (1985). Debt, deficits, and finite horizons. Journal of Political Economy, 93(2), 223-247.

Coccia, M. (2017). Asymmetric paths of public debts and of general government deficits across countries within and outside the European monetary unification and economic policy of debt dissolution. The Journal of Economic Asymmetries, 15, 17-31.

de Castro, F., \& Fernández, J. L. (2013). Does ricardian equivalence hold? The relationship between public and private saving in Spain. Journal of Applied Economics, 16(2). 251-274.

Feldstein, M. (1982). Government deficits and aggregate demand. Journal of Monetary Economics, 9, 1-20.

Fournier, J-M and Fall, F. (2017). Limits to government debt sustainability in OECD countries. Economic Modelling xxx (xxxx) $\mathrm{xxx}-\mathrm{xxx}$.

Ghatak, A., \& Ghatak, S. (1996). Budgetary deficits and Ricardian equivalence: the case of India, 1950-1986. Journal of Public Economics, 60(2), 267-282.

Gogas, P., Plakandaras, V., \& Papadimitriou, T. (2014). Public debt and privateconsumptio in OECD countries. The Journal of Economic Asymmetries, 11, 1-7.

Haris, A., \& Mohammad, A, K. (2015). Federal government debt and private consumption: the Malaysian experience. Journal of Scientific Research and Development, 2 (12), 64-69.

Hausman, J. (1978). Specification tests in econometrics. Econometrica, 46, 1251-1271.

Karras, G. (1994). Government spending and private consumption: some international evidence. Journal of Money, credit and Banking, 26(1), 9-22.

Khalid, A.M. (1996.) Ricardian equivalence: empirical evidence from developing economies. J. Develop. Econ., 51, 413432.

Kochin, L., (1974). Are future taxes anticipated by consumers? Comment. Journal of Money, Credit, and Banking, 6, 385394.

Kormendi, R. (1983). Government debt, government spending, and private sector behaviour. American Economic Review (December), 994-1010.

Li, Shaoyu \& Wei, Lijia \& Xu, Zhiwei. (2017). Dynamic asset allocation and consumption under inflation inequality: The impacts of inflation experiences and expectations. Economic Modelling, 61, 113-125.

Linnemann, L. (2006). The effect of government spending on private consumption: a puzzle?. Journal of Money, Credit, and Banking, 38(7), 1715-1735.

Michel, P. \& Thibaulth, E. (2007). The failure of Ricardian equivalence under dynastic altruism. Journal of Mathematical Economics, 43, 606-614.

Oseni, Isiaq Olasunkanmi. (2016). Exchange rate volatility and private consumption in Sub-Saharan African countries: A system-GMM dynamic panel analysis. Future Business Journal, 2, 103-115.

Paret, Anne-Charlotte (2017). Debt sustainability in emerging market countries: Some policy guidelines from a fanchart approach. Economi Modelling, 63, 26-45.

Pesaran, H. M., Shin, Y., \& Smith, R. P. (1999). Pooled Mean Group estimation of dynamic heterogenous panels. Journal of the American Statistical Association, 94, 621-634.

Pesaran, M. H., \& Smith, R. (1995). Estimating long-run relationships from dynamic heterogeneous panels. Journal of econometrics, 68(1), 79-113.

Pettinger, T. (2009). Economics Help. Ricardian Equivalence. Access on 20 October 2016.

Pozzi, Lorenzo (2006). Ricardian equivalence under imperfect information. Journal of Public Economics, 90, $2009-2026$.

Prohl, S., \& Schneider, F. G. (2006). Sustainability of public debt and budget deficit: Panel Cointegration analysis for the European 
Union member countries (No. 0610). Working Paper, Department of Economics, Johannes Kepler University of Linz.

Reitschuler, G., (2008). Assessing Ricardian equivalence for the New Member States: Does debt-neutrality matter?. Economic Systems, 32, 119-128.

Reiter, M., (1997). Ricardian equivalence with uninformed consumers? European Journal of Political Economy, 1, 747-758.

Ricardo, D. (1817). On the principles of political economy and taxation, in P. Sraffa (ed.), The works and correspondence of David Ricardo, Volume I, 1951, Cambridge University Press, Cambridge.

Seater, J. J., \& Mariano, R. S. (1985). New tests of the life cycle and tax discounting hypotheses. Journal of Monetary Economics, 15(2), 195-215.

Soon, S. V., Baharumshah, A. Z., \& Shariff, N. S. M. (2017). The persistence in real interest rates: Does it solve the intertemporal consumption behavior puzzle?. Journal of International Financial Markets, Institutions and Money, 50, 3651. 